\title{
W odpowiedZI NA UWAGi ZbignieWA NaWrockiego
}

Odnosząc się do uwag Zbigniewa Nawrockiego dotyczących mojej recenzji z książki Historyczne kamienice w Toruniu. Gotyk (Toruń 2016), chciałbym ustosunkować się tylko do dwóch kwestii. Po pierwsze, w recenzji nie padło stwierdzenie propagowania metod nieinwazyjnych. Jest rzeczą oczywistą, że pełne badania architektoniczne wykonać można jedynie podczas prac budowlano-konserwatorskich, gdy spod tynków w pełni odsłonić można strukturę muru. Niemniej jednak istnieje duża potrzeba doskonalenia i tych metod. Taki cel przyświecał właśnie projektowi badawczemu prowadzonemu przez pracowników Wydziału Sztuk Pięknych Uniwersytetu Mikołaja Kopernika w Toruniu.

Po drugie, z całą stanowczością chciałbym jeszcze raz podkreślić potrzebę intensyfikacji interdyscyplinarnych badań naukowych dla omawianego zespołu. Wykorzystanie różnych metod, przeważnie niemożliwych przy standardowych dokumentacjach konserwatorskich, pogłębić może naszą wiedzę nad przeszłością miasta. Za przykład niech posłuży wspomniana przez autora „gotycka" więźba w kamienicy na ul. Mostowej 6.

Szczegółowe badania architektoniczne, a potem dendrochronologiczne konstrukcji drewnianej wykazały, że drewno do jej budowy zostało ścięte w latach czterdziestych XVI w. Częściowo przekształcona została pod koniec XVII w. Drewno sosnowe użyte do jej wykonania zostało spławione $\mathrm{z}$ terenów Warmii.

Większa ilość informacji na temat datowania, rodzaju i pochodzenia budulca w domach toruńskich może zmienić chronologię przekształceń poszczególnych budynków. Stać się może również impulsem do dalszych rozważań nad historycznymi technikami budownictwa czy w końcu kontaktami handlowymi mieszczan toruńskich. To oczywiście tylko jedna z możliwości.

Polemika $\mathrm{z}$ autorem odnośnie do kwestii szczegółowych wydaje się już zbyteczna. Niech każdy czytelnik wyciągnie własne wnioski.

Maciej Prarat (Toruń) 